\title{
ADMINISTRATIVE PROBLEMS OF FINANCIAL RESPONSIBILITY LAWS
}

\author{
Robbins B. Storcker*
}

The first financial responsibility law in the United States was enacted by the Connecticut General Assembly of I925, to become effective on January I, I926. It was drawn by the writer who was at that time Commissioner of Motor Vehicles for Connecticut. It seemed to be accepted by the Connecticut Legislature as a substitute for a mass of proposed compulsory insurance legislation which had considerable public support but was opposed by insurance interests and thought impractical for state administration. ${ }^{1}$

So the financial responsibility law was born. Its purpose was, and is, to secure a larger percentage of responsible autoists on the highway. Laws built upon this theory are planned to provide a financial guarantee for satisfactory operating conduct from such persons as come under their provisions, namely, those who have violated specified motor vehicle laws ${ }^{2}$ or have been determined responsible for death or serious accident.

'Their enforcement in states and provinces which have operators' licensing systems is usually entrusted to the state authority. in charge of motor vehicles and was consequently expected to be a simple procedure, because the filling of all requirements under them can be, and is, made a condition precedent to either the issuance of a new license or the return of one which has been suspended.

This article cannot scrutinize the detailed provisions of these laws, already enacted in thirty states and territories and eight Canadian provinces ${ }^{3}$ but will concern itself

- B.A., I893, M.A. (hon.) I928, Yale University; LL.B.x 1895, New York Law School; M.A. (hon.), 1925, Trinity College. Member of Connecticut Bar. State Commissioner of Motor Vehicles, Connecticut, I917-1933. Research Associate in Highway Transportation, Yale University. Co-author, with M. A. May and R. S. Kirby, of Sense and Safety on the Road (Appleton-Century Co., 1936).

${ }^{2}$ Compulsory insurance as then proposed was to be based upon a theory of state underwriting and upon the idea that insurance companies might be obliged to write all risks at rates to be prescribed by the state.

${ }^{2}$ In the Connecticut Act the requirement is that a sufficient guarantee must be provided to satisfy any claim for damages arising from personal injury or death to at least $\$ 10,000$ and for damage to property of at least $\$ 1,000$ the qualification to be supplied by-( $x$ ) insurance policy, (2) surety company bond, (3) deposit of money or collateral, (4) real estate lien. The qualification by insurance is the only method enough used to call for further discussion except to remark that in an occasional case one of the other methods is applicable and meets the conditions.

${ }^{3}$ These laws are analyzed in Braun, the Financial Responsibility Law, supra p. 505. For a brief discussion of these laws, reference may be made to Stoecket, MAY, AND KiRBY, SENSE aNd SAFETX ON THE RosD ( $\mathrm{xg3} 6$ ). 
with certain administrative problems which they pose. These problems are taken from over seven years experience with the Connecticut law, which has differed in two important respects from the financial responsibility laws enacted elsewhere.

The original form of the law in this state was amended in $x 929$ to include a system of "rating risks" under which the Commissioner of Motor Vehicles was required to classify persons ordered to furnish proof into classes, depending upon the character of their past performance records, the seriousness of their present offenses and of the injuries caused by them, and their degree of responsibility therefor. ${ }^{4}$ This requirement was made possible because of the complete and inclusive records of operators' performance on file in the department. The plan provided a financial inducement to be careful. Its purpose was to make it cost money to be irregular in one's driving; also, it was hoped that because of the inducement of additional premium for bad records, insurance guarantors might even be more careful in selection of risks and that there might be some risks at least too undesirable to write at all, notwithstanding high premiums.

Administration under this feature of the act was complicated and difficult. It required detailed checking and examination of records. But the main difficulties in management grew out of the fact that the requirement of financial responsibility under this law attaches to a person and not to the automobile. It could therefore be easily evaded by a change in the car ownership and registration. This practice became popular as a means of evasion (especially by operators in Classes B and C) because of the size of the premiums required to be paid by anyone included in either of the advanced offender classes. Consequently the merit system was dropped

‘Conn. Public Acts 1929, c. 200, \$4. Classification. The Commissioner shall classify all persons from whom he shall require proof of financial responsibility in three classes in accordance with the seriousness of the offenses which shall have been committed by them or of the injuries or damages which shall have been caused by the accidents in which they shall have been coneerned as set forth in section one hereof. Such classes shall be known as classes A, B and C. Those persons who shall have committed the least serious offenses or been, in the opinion of the commissioner, at least partially responsible for accidents which shall have caused the least serious injuries or damage or for the occurrence of which they shall have been least responsible shall be classified in class $A$; those who shall have committed more serious offenses or, in the opinion of the Commissioner, shall have been at least partially responsible for accidents causing more serious injuries or damage or shall have a greater degree of responsibility for such accidents shall be classified in class $B$ and those who shall have committed the most serious offenses or, in the opinion of the commissioner, shall have been at least partially responsible for accidents causing the most serious injuries or damage, which the commissioner shall determine will not bar such person from receiving operators' licenses or renewals thereof as persons whom he shall deem incapable of operating a motor vehicle with safety to themselves and the public, shall be classified in class C. . . . If the person insured or bonded shall be classified in class $A$, the premiums at standard rate, without modification except as provided by such rules for the development of experience rates as hereinbefore specified, plus ten percentum of such premiums as are charged for the proof of financial responsibility hereinbefore required; if such person shall be classified in class $B$, the premiums at standard rate, without modification as hereinbefore specified, plus twenty-five pereentum of such premiums as are charged for the proof of financial responsibility hereinbefore required; and if such person shall be classified in class $C$, the premiums at standard rate, without modification as hereinbefore specified, plus fifty percentum of such premiums as are charged for the proof of financial responsibility hereinbefore required. The commissioner may require from any company issuing such policy or bond full information concerning the facts and figures upon which any experience rate may be based. 
from the law, first, by a departmental ruling in $1932,{ }^{5}$ and, subsequently, in the revision of the law by the Legislature in $1933 .^{6}$

Another feature in which the Connecticut law differs from most similar laws is that it has not included any provision for the filing of proof upon the failure to satisfy a civil judgment arising out of a motor accident suit. From I929 to I93I Connecticut had a separate statute on this point which required the Commissioner of Motor Vehicles to suspend and withhold an operator's license upon certification of such a condition. This law was found by the Legislature to have been misused in that it made the Department of Motor Vehicles, instead of the courts, an agency for collecting damages. It seemed not to be a safe driving measure and was repealed in $193 .^{7}$ There is now no such provision in the law.

The problem of jurisdiction. Greatest among the problems of administration has been the one occasioned by the rapid and extreme increase in numbers of motor vehicles in use. In planning his appropriation, a state administrator was at once embarrassed by the size of the undertaking. When the Connecticut law was drafted in $x 925$ the first necessary step in administration was to form an estimate of the number of cases to be managed. The estimate was set largely upon conjecture, at about seven percent of the registration, to include from ten to fifteen thousand cases. The steadily increasing numbers of automobiles registered and of offenders who came under the requirement to furnish proof outgrew the capacity of the administrator's appropriation and left a choice between slighting the work or narrowing the jurisdiction. The latter was the course adopted, and year after year the jurisdiction has become less inclusive until now the only types of offenses which can be included and disposed of are the more serious ones. This problem has apparently presented itself elsewhere, but other states have had the advantage of being able to profit by Connecticut's experience in narrowing the jurisdiction so that their problem has been less acute.

In actual practice, cases are received automatically at the office of the Commissioner of Motor Vehicles each day in the usual course of business in the form of an abstract record, required by law, from the clerk of each court of each motor vehicle law violation. (All courts, including coroners, report currently.) Accidents occasioning personal injury and damage in excess of $\$ 25$ are reported promptly. Efficiency in these two activities has been insisted upon, and it is safe to claim that no considerable number of cases fail to reach the Commissioner's office. Many of them, especially those which involve death, are often reported in detail and the responsibility fixed by the court. There is no criticism to be considered relating to this feature.

${ }^{\circ}$ On October 27, 1932, the method of requiring owner and operator in each case to furnish proof of financial responsibility was changed to attach to the operator only. This application of the statute greatly reduced the number of insurance certificates required and made the safe driving element more effective by climinating the possibility of evasion of the requirement by operators who previously had not been required to furnish proof of financial responsibility for their driving of any car if the owner of the car involved had complied with the requirement.

"Conn. Gen. Stat. (Cum. Supp. I933) \$444b.

${ }^{7}$ Conn. Pub. Acts 1931, c. 282, \$9. 
The coöperation has always been good and a satisfactory working record is provided by it.

The problem of constitutionality. As at first planned, all such laws had, as an essential point, application of discretion on the part of a state official. That is, it was expected that every state administrator could invoke the law against any offender, but a point was early raised that to include an offender as a matter of discretion might be a "judicial act" and therefore out of the constitutional powers of an administrative office. This objection was urged in a number of instances and had so much apparent force as to cause amendments of laws. ${ }^{8}$ Such amendments purported to serve the purpose on the theory that the law itself would select offenders by their direct inclusion by classifications, leaving to the administrator only the duties of application and enforcement. They narrowed the field still more and wiped out all of the corrective procedure which state administrators could have otherwise applied in the thousand and one cases arising where, for purposes other than highway safety, original charges had been mitigated by prosecutors and courts or where cases had been nolled for payment of a sum of money.

This problem raised a technical difficulty only, yet it was a serious one in its effect. While it is true that the loophole provided by the nolle is apparently closed by a statutory provision that a nolle of any type shall be considered a conviction, the very fact that the court record on a nolle is usually simply a statement of the fact without evidence and without comment, results in the loss of the value of the record for the application of the financial responsibility requirement. There has been no attempt, as yet, to prevent the changing of charges, and the fact persists that often a prosecutor will accept a plea of guilty to a lesser offense so as not to have to actually try the case.

The problem of securing the coöperation of insurers. The whole principle of financial responsibility is based upon the desirability of selection of risks by insurance underwriters. In actual enforcement, this state supplies records of past performance of operators and because, in all jurisdictions, at least $90 \%$ of all those who operate motor vehicles are owners in the legal sense of the word at least, it was expected by lawmakers that insurance companies would invariably investigate every risk offered and, if found hazardous on past performance of an owner, would take such steps as might be proper, either refusing the risks entirely or calling for additional security

\footnotetext{
${ }^{8}$ Thus the Connecticut law originally authorized the Commissioner to require proof not only in cases of conviction for violation of specific motor vehicle laws but also where the "operator shall have been involved in, and, in the opinion of said Commissioner, responsible in whole or in part for any motor vehicle accident resulting in the death of, or injury to, any person, or damage to property to the extent of at least fifty dollars." ConN. GEN. STAT. (1930) \$1609 (a). The broad grant to the Commissioner of discretionary power to determine responsibility was narrowed in 193 I by the deletion of and the substitution therefor of the requirement to furnish proof where the operator "shall have been held or found criminally responsible in connection with any motor vehicle accident, resulting in the death of any person or who has a record on file with the commissioner of motor vehicles which is sufficient, in the opinion of said commissioner, to require evidence of financial responsibility for the reasonable protection of other persons." Conn. Pub. Acts I93I, c. 82. Only the last clause accords discretionary power.
} 
from the applicant as might seem practical as an inducement to safeguard the risk. This has worked out only to a limited extent.

Good business practice on the part of insurance companies, meaning economy in management, apparently has made the procedure, originally intended as a safety measure for the benefit of the citizens of the state, primarily a convenience and credit research procedure for the companies. It is true that such laws have produced good results through the coöperation of insurance interests. In extreme cases as, for instance, drunken driving, there is nearly perfect administration, but when the point is reached where the interest of a state is contrary to the direct financial interest of the insurance company, then, as is to be expected, the company feels obliged to follow the best business lines for itself. Coöperation, then, is limited. Its limit is the extent to which the purposes of the state by the enforcement of its financial responsibility follows and agrees with good insurance practice. With all of its shortcomings, such a law is good on the basis of the results, however limited, which have been accomplished. Yet there are endless small worries in administration for an official when he tries, as he must, to fit his work to insurance practices.

The problem of cancellation of insurance certificates. Thousands of policies written under the jurisdiction of the law by sanguine insurance agents, and they are all sanguine, have to be cancelled because of non-payment of premiums. The state office accordingly has to put through a withdrawal of coverage, and the administrator and his subject have to begin anew.

Apparently insurance companies do not feel justified in going to the expense of purchasing the state records except in a limited number of the more serious cases. The use of this record should be more inclusive. A practice has arisen whereby the information is secured through a credit rating bureau service to which many companies subscribe and which supplies a financial and character record as well as the driving record of the subject. From the standpoint of the person who has been ordered to supply a guaranty there have been many annoyances and to some extent he has been unfairly treated. Often his car has been a vital part of his business life. He has to have it to use, his family support depends upon it, but, because he cannot pay the premium to protect the public by an insurance policy, a state administrator, with the best intention in the world, cannot help him. The operator has been obliged either to operate illegally, get someone to assume title who does not need insurance, or be deprived of the use of his car and take up other means of livelihood where a car is not necessary.

One of the principal means of evasion of such laws has been hinted at. A subject could change his registration and put his car into another's ownership, thereby avoiding the whole application of such laws and leaving the conditions as they originally existed with reference to his driving. To solve this problem, which was a serious one, the law was amended to include a coverage for the operation of any car by the operator. This seemed to provide an ideal prospect for solution, but when insurance actuaries got to work it became apparent that this coverage could not be written 
except for a high premium-so high in fact as practically to dispose of this form of coverage as a solution. It has been, and still is, ordered in very extreme cases.

Reciprocity between states. The fact that the motor vehicle has such a wide cruising range forced the development of coöperation between states under reciprocal agreements. It is now a fact that, in serious cases or in the course of assistance in police measures, any state can call for and receive the assistance of any other to the full extent of its powers for the enforcement of motor vehicle laws. Practice between states has even developed into a system of exchanging information so that if a Connecticut driver, for example, be convicted of a serious offense in Massachusetts, the Massachusetts Department sends the information to Connecticut, at the same time disciplining the offender, perhaps by a suspension of his right to operate a car in Massachusetts. Following that, Connecticut considers his offense and, should it come under the provisions of the Connecticut law or the Commissioner's discretion, his operator's license may be suspended. This coöperation extends at the present time to all serious offenses against motor vehicle laws and has been used to help enforce financial responsibility laws. Connecticut coopperates in the same manner with other states, and it is seldom, if ever, that an administrator has not responded promptly when called upon for suspension action for any serious offense.

Suggested future procedurre. It would probably be beyond expectation if, after pointing out the administrative difficulties which beset such laws, the writer did not indicate his opinion as to some remedy and add some reflections to this paper. In the first place, too much has been expected of laws of this nature. They cannot be inclusive but ought only to be used by a state for most limited jurisdictional offenses. This means that the requirement to furnish proof should be imposed judicially as a part of the penalty for an offense when an operator is convicted and that the state administrator should have only to see to its subsequent enforcement upon the operator.

Further, there must be a better adaptation of state practice to insurance company procedure. Now that the limits of possible coöperation and enforcement are better understood, the accomplishment ought to become more limited and perfected. 